\title{
Non-Target Lesion Identification
}

National Cancer Institute

\section{Source}

National Cancer Institute. Non-Target Lesion Identification. NCI Thesaurus. Code

C94521.

The identification of a lesion that is not considered a target lesion but may be affected by the therapeutic intervention. 